\title{
Micronuclear induction in response to methylmercury exposure in the air breathing fish Anabas testudineus (Bloch, 1792)
}

\author{
S. SWETHA AND R. B. PRAMOD KIRAN \\ Department of Aquatic Biology and Fisheries, University of Kerala, Karyavattam, Thiruvanathapuram - 695581 \\ Kerala, India \\ e-mail:sswetha15@gmail.com
}

\begin{abstract}
Natural and man-made chemicals like mercury have been implicated as malefactors in various ailments and are even considered genotoxic since long. Methylmercury $(\mathrm{MeHg})$, the organic compound of mercury, is known to cause genetic variations in many organisms spanning all spheres of life. The present study was conducted to identify the formation of nuclear anomalies on exposure to $\mathrm{MeHg}$ in the freshwater air breathing fish Anabas testudineus (Bloch, 1792), using micronucleus $(\mathrm{MN})$ assay. Acute toxicity $\left(\mathrm{LC}_{50}\right)$ of $\mathrm{MeHg}$ was calculated to be $438 \mu \mathrm{g} \mathrm{l}^{-1}$ using probit analysis. The fishes were exposed to $1 / 5^{\text {th }}$ concentration of $\mathrm{LC}_{50}\left(87.6 \mu \mathrm{g} \mathrm{l}^{-1}\right)$ and blood samples collected on days 0,4 and 15 were analysed for induction of MN. The percentage of MN formation per 1000 cells was the highest (19.35) in the juveniles on day 15 . It is concluded that $A$. testudineus is sensitive to $\mathrm{MeHg}$ and micronuclear assay of the species can be used as a potential biomarker in the event of contamination in aquatic ecosystems.
\end{abstract}

Keywords: Anabas, MeHg, Micronucleus, Sublethal

Small nucleus formed during the process of cell division where a chromosome or a piece of a chromosome is not incorporated into one of the daughter nuclei forms the micronucleus $(\mathrm{MN})$ and is a sign of genotoxicity and chromosomal instability. Micronuclei known as Howell-Jolly bodies were discovered in the late $19^{\text {th }}$ century by William Howell and Justin Jolly (Sears and Udden, 2011) but their significance was understood only in the mid-20 $0^{\text {th }}$ century (Dawson and Bury, 1961). Till then, these were considered to be debris of malformed RBCs (Sears and Udden, 2011). The formation of MN was reported to be a reliable test for measuring in vivo DNA damage caused by contaminants (Fenech and Morley, 1985). MN formed are created from lagging acentric chromosomes or chromatid fragments caused by incorrectly repaired or unrepaired DNA breaks, or by the non-disjunction of chromosomes, hypomethylation of repeat sequences situated in pericentromeric DNA or the inconsistencies in kinetochore proteins or their assembly, impaired spindle apparatus or flawed anaphase checkpoint genes (Fenech et al., 2011). MN assays have been developed to test for the presence of these structures and to determine their frequency in cells exposed to certain chemicals or subjected to stressful conditions. The present study was conducted to investigate $\mathrm{MN}$ induction in the freshwater air breathing fish Anabas testudineus (Bloch, 1792), on exposure to methylmercury (MeHg).
Median lethal toxicity of $\mathrm{MeHg}$ for $A$. testudineus fingerlings (mean total length $7.07 \pm 0.7 \mathrm{~cm}$ and mean weight $6.48 \pm 2.112 \mathrm{~g}$ ) was determined as perAPHA(2012). Acute lethal toxicity $\left(\mathrm{LC}_{50}\right)$ was estimated as $438 \mu \mathrm{g} \mathrm{l^{-1 }}$ using probit analysis after conducting definitive toxicity tests.

For the micronuclear (MN) induction experiment, two sets of $A$. testudineus were utilised. Each set of fish was of different length and were from the juvenile and mature life stages. Twenty-five fish, each of average length $9.27 \pm 0.62 \mathrm{~cm}$ and weight $11.96 \pm 2.36 \mathrm{~g}$ considered juvenile, and average length $13.96 \pm 0.93 \mathrm{~cm}$ and weight $36.86 \pm 10.10 \mathrm{~g}$ considered mature, were exposed to sublethal concentration $\left(1 / 5^{\text {th }}\right.$ concentration of $\mathrm{LC}_{50}$ i.e., $87.6 \mu \mathrm{g} \mathrm{l}^{-1}$ ) of $\mathrm{MeHg}$ by immersion method. Twenty-five fish, each of the two size-groups, were released in toxicant-free water which served as control for the respective set. Five fish each were randomly sampled from each set exposed to the sublethal concentration of $87.6 \mu \mathrm{g} \mathrm{l}^{-1}$, on days 0,4 and 15 . Semi-static renewal of water was carried out every four days and the fish were subjected to intermittent feeding. Blood was collected from the sampled fish by cardiac puncture using a heparinised insulin syringe (U-40) holding ultrafine needle, from the juvenile, mature and control groups and then smeared on to two clean slides each. The slides were processed according to the method of Palhares and Grisolia (2002) and stained with 5\% Giemsa's stain. From each fish, 6000 
erythrocytes were counted on slides prepared from each group. The frequencies of $\mathrm{MN}$ were analysed using a binocular microscope (Leica, BME) under oil-immersion objective. The extranuclear entity with a round, smooth perimeter membrane having no connection with the main nucleus which stains similar to the nucleus, measuring $1 / 3^{\text {rd }}$ to $1 / 10^{\text {th }}$ of the main nucleus (Ayllon and Garcia-Vazquez, 2000) was considered an MN. The presence of $\mathrm{MN}$ was analysed as the number of $\mathrm{MN}$ in every thousand erythrocytes (MN\%o) using the formula suggested by Ali et al. (2009).

$$
\text { MN\%o }=\left(\frac{\text { Number of micronuclei counted }}{\text { Total number of erythocytes counted })}\right) * 100
$$

Statistical significance was analysed using the Student's t-test $(p<0.05)$ on the mean values of the experimental and control group data.

The data on the induction of $\mathrm{MN}$ in mature and juvenile $A$. testudineus exposed to $\mathrm{MeHg}$ are presented in Fig. 1 and 2. There was an increase in the $\mathrm{MN}$ induction in both the age groups of fishes exposed to $\mathrm{MeHg}$. The increase was significant $(\mathrm{p}<0.05)$ in all the experimental groups exposed to $\mathrm{MeHg}$ and the increase was found to be comparativley more in the case of juveniles than mature fishes. Induction of MN showed highly significant $(\mathrm{p}<0.01)$ difference between day 0 and day 4 samples. No significant difference in $\mathrm{MN}$ induction was observed between day 4 and day 15 samples in the case of juveniles. $\mathrm{MN}$ induction in mature fish, saw a massive increase from the fourth day to the $15^{\text {th }}$ day, whereas for the juveniles, there was an abrupt increase in the number of $\mathrm{MN}$ on the fourth day followed by a steady increase till the $15^{\text {th }}$ day. The results showed significant values $(p<0.05)$ on day 4 and highly significant value $(\mathrm{p}<0.01)$ on day 15 , compared to the control values. The results showed that there are more MN formed (per thousand cells) in the juveniles during each sampling. Photomicrographs of normal and micronucleated erythrocytes recorded are documented in Fig. 3 and 4.

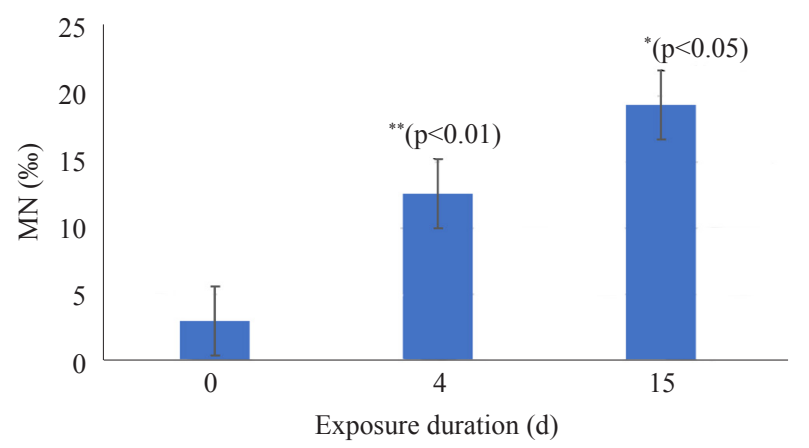

Fig. 1. Micronuclear induction in juvenile $A$. testudineus exposed to $\mathrm{MeHg}$ at various exposure durations

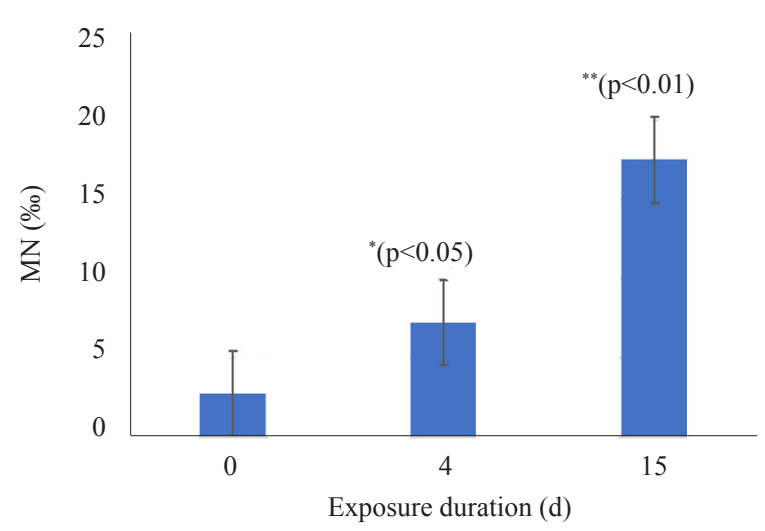

Fig. 2. Micronuclear induction in mature $A$. testudineus exposed to $\mathrm{MeHg}$ at various exposure durations

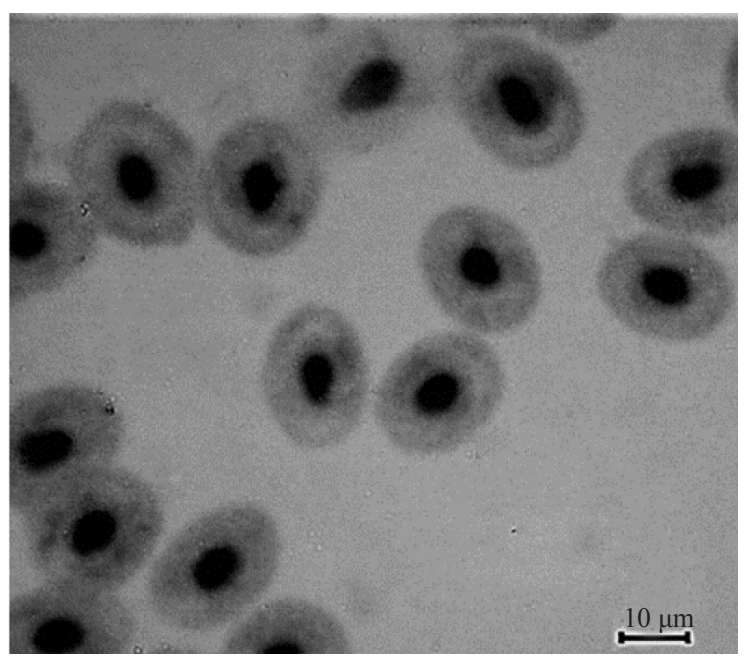

Fig. 3. Normal erythrocytes of $A$. testudineus showing elliptical shape and ovoid nucleus

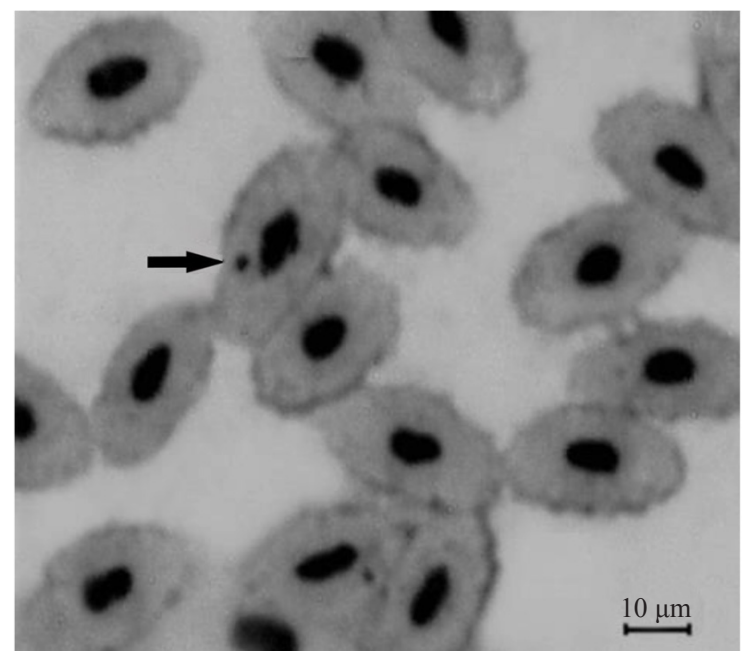

Fig. 4. Erythrocyte showing micronucleus (arrow) after exposure to $\mathrm{MeHg}$ 
Many chemicals in the aquatic environment are not only dangerous for the physiology, but also induce genetic alterations which may lead to mutations (Russo et al., 2004). Species are affected as generations are unfit to reproduce and have lowered viability and the ones that survive have congenital genetic disorders. Mercury is one of the widely present, persistent and hazardous environmental contaminants that occur in a wide variety of physical and chemical states (WHO, 1990; Bonacker et al., 2004). The genotoxic effects of different mercury compounds on different fish species have been demonstrated. Mercury chloride is known to interfere in the regular chromosome segregation during cell division by inhibiting the actin tubule polymerisation that forms the basic structure of the mitotic spindle (Miura and Imura, 1987). Clastogenic effects on human chromosomes exposed to $\mathrm{MeHg}$ have been reported (Betti et al., 1992; Ogura et al., 1996; Amorim et al., 2000). The toxic chemicals producing genotoxic effects form reactive oxygen species (ROS) as well as electrophilic free-radical metabolites which react with DNA, causing disruptive changes. Heavy metal exposure forms electrophilic ions and radicals, which interact with the nucleophilic sites in DNA causing strand breaks and other damages in the genes of the organism.

The presence of $\mathrm{MN}$ in cells is a reflection of structural and/or numerical chromosomal aberrations arising during mitosis (Heddle et al., 1991). Most of the studies conducted on MN formation by chemical pollutants used intraperitoneal injection of the concerned chemicals but in the environment, the chemicals are either dissolved or suspended which gives a varied result when compared to the laboratory results. The present study utilised immersion method and it has been used in laboratory experiments like those on Cyprinus carpio for mercury (Nepomuceno et al., 1997) and Cheridon interruptus interruptus for pyrethroids (Campana et al., 1999). Immersion method is considered to provide a realistic picture of the environmental pollution and bioaccumulation. Basal or natural, or spontaneous levels of $\mathrm{MN}$ in fish species are relatively low (Ferraro et al., 2004). In the present study, baseline or spontaneous MN induction in the control group was minimal with mean frequency of $0.00286 \pm 0.00140$. The $\mathrm{MN} \%$ in the control group was 2.89. In situ studies with different fish species have reported basal MN levels between 0.8 and $2.76 \%$ o (Rodriguez-Cea et al., 2003). The rate of MN induction in various species shows general peak between the first and the fifth days of exposure (Al-Sabti and Metcalfe, 1995; Grisolia and Cordeiro, 2000) but in this study the peaks varied with higher MN at 15 days of exposure. da Rocha (2011) showed induction of $\mathrm{MN}$ and other nuclear abnormalities in erythrocytes of Colossoma macropomum (tambaqui) exposed to $2 \mathrm{mg} \mathrm{l}^{-1}$ of $\mathrm{MeHg}$. MN assay in erythrocytes is a mutagenicity assay and is less sensitive than comet assay (Russo et al., 2004). According to many studies, a direct relationship between the MN frequencies and heavy metal concentrations in water exists along with species sensitivity (Al-Sabti, 1994, 1995; Sanchez-Galan et al., 1999, 2001). Significant increase in the frequency of $\mathrm{MN}$ in fish collected from highly contaminated rivers was reported for Barbus plebejus (Minissi et al., 1995), Lepidocephalus sp. (Poongothai et al., 1996) and Salmo trutta (Sanchez-Galan et al., 1998). Grisolia and Starling (2001) reported a high increase in the number of $\mathrm{MN}$ in C. carpio, Oreochromis niloticus and Tilapia rendali in the Paranoa Lake, Brazil, which is a dump for the municipal waste waters from the coastal towns. In most studies, exposure periods between 24 and $96 \mathrm{~h}$ were sufficient to produce $\mathrm{MN}$ and the erythrocytes are considered as genotoxicity biomarkers (Heddle et al., 1991; Ayllon and Garcia-Vazquez, 2000). In this study, the selected fish A. testudineus had very high levels of $\mathrm{MN}$ induction. The difference in the induction of MN could be attributed to the species of fish selected for the experiments. This observation is supported by Rodriguez-Cea et al. (2003) who stated that some fish species (e.g., brown trout) are more sensitive to genotoxic pollutants than other species such as Anguilla anguilla and Phoxinus phoxinus.

Thus, from the results of the present study, it can be concluded that $\mathrm{MeHg}$ is a potential genotoxic agent and $A$. testudineus erythrocytes are good biomarkers for evaluating the genotoxic potentials of waterborne pollutants. The study also confirmed that the frequency of $\mathrm{MN}$ induction increases with increase in duration of exposure to the toxicant and that the juveniles seem to be more prone to the damage induced in the nuclear material. This could be due to the higher rates of cellular division and metabolism. Methylmercury is known to be toxic to tubulin interfering with spindle fibre formation and causing delayed centromeric division as well as reduced anaphasic movement (da Rocha et al., 2009).

\section{Acknowledgements}

The authors thank Dr. A. Biju Kumar and Dr. K. Padmakumar, Department of Aquatic Biology and Fisheries, University of Kerala for the facilities provided. The first author acknowledges financial assistance provided by the University of Kerala for the research work. The paper was presented in $11^{\text {th }}$ Indian Fisheries and Aquaculture Forum (11IFAF), 21 - 24 November 2017, Kochi, Kerala, India.

\section{References}

Ayllon, F. and Garcia-Vazquez, E. 2000. Induction of micronuclei and other nuclear abnormalities in European minnow Phoxinus phoxinus and mollie Poecilia latipinna: An assessment of the fish micronucleus test. Mutat. Res., 467: 177-186. doi: 10.1016/s1383-5718(00)00033-4. 
Ali, D., Nagpure, N. S., Kumar, S., Kumar, R., Kushwaha, B. and Lakra, W. S. 2009. Assessment of genotoxic and mutagenic effects of chlorpyriphos in freshwater fish Channa punctatus (Bloch) using micronucleus assay and alkaline single-cell gel electrophoresis. Food Chem. Toxicol., 47: 650-656. doi: 10.1016/j.fct.2008.12.021.

Al-Sabti, K. 1994. Micronuclei induced by selenium, mercury, methylmercury and their mixtures in binucleated blocked fish erythrocyte cells. Mutat. Res., 320: 157-163. doi: 10.1016/0165-1218(94)90068-x.

Al-Sabti, K. 1995. An in vitro binucleated blocked hepatic cell technique for genotoxicity testing in fish. Mutat. Res., 335: 109-120. doi: 10.1016/0165-1161(95)90048-9.

Al-Sabti, K. and Metcalfe, C. D. 1995. Fish micronuclei for assessing genotoxicity in water. Mutat. Res., 343: 121-135. doi: 10.1016/0165-1218(95)90078-0.

Amorim, M.I., Mergler, D., Bahia, M.D., Dubeau,H., Miranda,D., Lebel, J., Burbano, R. R. and Lucotte, M. 2000. Cytogenetic damage related to low levels of methylmercury contamination in the Brazilian Amazon. An. Acad. Bras. Cienc., 72: 487-507. http://dx.doi.org/10.1590/S0001-376 52000000400004.

APHA 2012. Standard methods for examination of water and wastewater. $22^{\text {nd }}$ edn. American Public Health Association, Washington, USA, $1360 \mathrm{pp}$.

Betti, C., Davini, T. and Barale, R. 1992. Genotoxic activity of methyl mercury chloride and dimethyl mercury in human lymphocytes. Mutat. Res., 281: 255-260. doi: 10.1016/0165-7992(92)90018-d.

Bonacker, D., Stoiber, T., Wang, M., Bohm, K. J., Prots, I., Unger, E., Thier, R., Bolt, H. M. and Degen, G. H. 2004. Genotoxicity of inorganic mercury salts based on disturbed microtubule function. Arch. Toxicol., 78: 575-583. doi: 10.1007/s00204-004-0578-8.

Campana, M. A., Panzeri, A. M., Moreno, V. J. and Dulout, F. N. 1999. Genotoxic evaluation of the pyrethroid lambda-cyhalothrin using the micronucleus test in the erythrocytes of the fish Cheirodon interruptus interruptus. Mutat. Res., 438(2): 155-161. doi: 10.1016/s1383-5718 (98)00167-3.

da Rocha, C. A. M., da Cunha, L. A., Pinheiro, R. H. S., Bahia, M. O. and Burbano, R. M. R. 2011. Studies of micronuclei and other nuclear abnormalities in red blood cells of Colossoma macropomum exposed to methylmercury. Gen. Mol. Biol., 34(4): 694-697. doi: 10.1590/S1415-47572011 000400024

Da Rocha, C. A. M., dos Santos, R. A., Bahia, M. O., da Cunha, L. A., Ribeiro, H. F. and Burbano, R. M. R. 2009. The micronucleaus assay in fish species as an important tool for xenobiotic exposure risk assessment - A brief review and example using neotropical fish exposed to methylmercury. Rev. Fish. Sci., 17(4): 478-484.
Dawson, D. W. and Bury, H. P. R. 1961. The significance of Howell-Jolly bodies and giant metamyelocytes in marrow smears. J. Clin. Pathol., 14(4): 374-380. doi: 10.1136/ jcp.14.4.374.

Fenech, M. and Morley, A. A. 1985. Measurement of micronuclei in lymphocytes. Mutat. Res., 147(1-2): 29-36. doi: 10.1016/0165-1161(85)90015-9.

Fenech, M. Kirsch-Volders, M., Natarajan, A. T., Surralles, J., Crott, J. W., Parry, J., Norppa, H., Eastmond, D. A., Tucker, J. D. and Thomas, P. 2011. Molecular mechanisms of micronucleus, nucleoplasmic bridges and nuclear bud formation in mammalian and human cells. Mutatgenesis, 26(1): 125-132. doi: 10.1093/mutage/geq052.

Ferraro, M. V. M., Fenocchio, A. S., Mantovani, M. S., Ribeiro, C. O. and Cestari, M. M. 2004. Mutagenic effects of tributyltin and inorganic lead (Pb II) on the fish H. malabaricus as evaluated using the comet assay and piscine micronucleus and chromosome aberration tests. Genet. Mol. Biol., 27: 103-107. http://dx.doi.org/10.1590/ S1415-47572004000100017.

Grisolia, C. K. and Cordeiro, C. M. T. 2000. Variability in micronucleus induction with different mutagens applied to several species of fish. Genet. Mol. Biol., 23:235-239. http:// dx.doi.org/10.1590/S1415-47572000000100041.

Grisolia, C. K. and Starling, F. L. 2001. Micronuclei monitoring of fishes from lake Paranoa, under influence of sewage treatment plant discharges. Mutat. Res., 491: 39-44.

Heddle, J. A., Cimino, M. C., Hayashi, M., Romagna, F., Shelby, M. D., Tucker, J. D. Vanprays, P. and MacGregor, J. T. 1991. Micronuclei as an index of cytogenetic damage: Past, present and future. Environ. Mol. Mutagen.,18: 277-291. doi: 10.1002/em.2850180414.

Minissi, S., Ciccoti, E. and Rizzoni, M. 1995. Micronucleus test in erythrocytes of Barbus plebejus (Teleostei, Pisces) from two natural environments: A biossay for the in situ detection of mutagens in freshwater. Mutat. Res., 367: 245-251. https://doi.org/10.1016/S0165-1218(96)90084-1.

Miura, K. and Imura, N. 1987. Mechanism of methyl mercury toxicity. CRC Crit. Rev. Toxicol., 18: 161-187.

Nepomuceno, J. C., Ferrari, I., Spano, M. A. and Centeno, A. J. 1997. Detection of micronuclei in the peripheral erythrocytes of Cyprinus carpio exposed to metallic mercury. Environ. Mol. Mutagen., 30:293-297 doi: 10.1002/ (sici)1098-2280(1997)30:3<293::aid-em7>3.0.co;2-m.

Ogura, H., Takeuchi, T. and Morimoto, K. 1996. A comparison of the 8-hydroxydeoxyguanosine, chromosomal aberrations and micronucleus techniques for the assessment of the genotoxicity of mercury compounds in human blood lymphocytes. Mutat. Res., 340: 175-182.

Palhares, D. and Grisolia, C. K. 2002. Comparison between the micronucleus frequencies of kidney and gill erythrocytes in tilapia fish, following mitomycin C treatment. Genet. Mol. Biol., 25: 281-284. http://dx.doi.org/10.1590/S141547572002000300005 . 
Poongothai, K., Shayin, S. and Usharani, M. V. 1996. Induction of micronuclei in fish by polluted water and heavy metals. Cytobios, 86: 17-22.

Rodriguez-Cea, A., Ayllon, F. and Garcia-Vazquez, E. 2003. Micronucleus test in freshwater fish species: An evaluation of its sensitivity for application in field surveys. Ecotoxicol. Environ. Saf., 56(3): 442-448. doi: 10.1016/s0147-6513 (03)00073-3.

Russo, C., Rocco, L., Morescalchi, M. A. and Stingo, V. 2004. Assessment of environmental stress by the micronucleus test and the comet assay on the genome of teleost populations from two natural environments. Ecotoxicol. Environ. Saf., 57: 168-174. doi: 10.1016/S0147-6513(03)00027-7.

Sanchez-Galan, S., Linde, A. R., Ayllon, F. and Garcia-Vazquez, E. 2001. Induction of mironuclei in eel (Anguilla anguilla L.) by heavy metals. Ecotoxicol. Environ. Saf., 49(2): 139-143. https://doi.org/10.1006/eesa.2001.2048.
Sanchez-Galan, S., Linde, A. R. and Garcia-Vazquez, E. 1999. Brown trout and European minnow as target species for genotoxicity tests: Differential sensitivity to heavy metals. Ecotoxicol. Environ. Saf., 43: 301-304. DOI: 10.1006 eesa.1999.1794.

Sanchez-Galan, S., Linde, A. R., Izquiredo, J. I. and Garcia-Vazquez, E. 1998. Micronuclei and fluctuating asymmetry in brown trout (Salmo trutta): Complementary methods to biomonitor freshwater ecosystems. Mutat. Res., 412(3): 219-225. DOI: 10.1016/S1383-5718(97)00186-1.

Sears, D. A. and Udden, M. M. 2011. Howell-Jolly bodies: A brief historical review. Am. J. Med. Sci., 343(5): 407-409. doi: 10.1097/MAJ.0b013e31823020d1.

WHO 1990. Environmental health criteria 101: Methylmercury. World Health Organisation, Geneva. http://www. americanchronicle.com/articles/view/109078. 